\title{
The epitaph of profession
}

Donald M Berwick

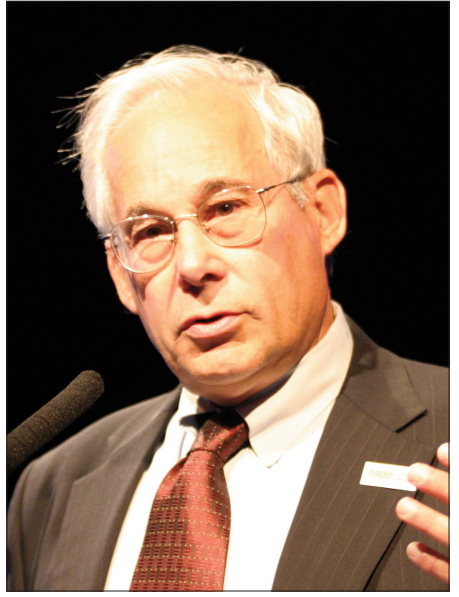

As a very young child growing up in a small town in rural Connecticut, I would half-awaken at some dark early morning hour, stirred by the sound of my father's car starting in the driveway. My father was a GP in our town - one of only two. He was up because he would have received a telephone call that night from Mrs Baron or Mr Bishop; maybe Izzie had chest pain or Millie had a high fever. He would have dressed, rubbed the sleep from his eyes, and climbed into his car to make the house call. I would drift back to sleep, and maybe in the morning l'd hear a bit of the story; Izzie was in the hospital, Claire was in labour. Someone had been born. Someone had died. That night, my mother might bring dinner to Millie to help her out.

DM Berwick, KBE, MD, MPP, FRCP (London), FRCGP, FRCPS (Glasgow), president and CEO, Institute for Healthcare Improvement, Cambridge, MA, US. This text is based on the John Hunt Lecture delivered at the Royal College of General Practitioners Annual National Conference on Primary Care, Bournemouth, on 2 October 2008.

Address for correspondence

Dr Donald Berwick, Institute for Healthcare Improvement, 20 University Road, 7th Floor, Cambridge, MA, 02138, US. E-mail: dberwick1@ihi.org

Submitted: 1 November 2008; Editor's response: 13 November 2008; final acceptance: 13 November 2008.

๑) Donald M Berwick, 2009.

This article was originally online first. Cite this article as: Br J Gen Pract 2009; 59: 128-131. Advance online publication. DOI 10.3399/bjgp08X376438
Once a day - once every single day for 40 years - my father would drive the 17 miles to the local hospital to make rounds on his patients, then return to his office for morning consultation hours, and afternoon hours, and, several days a week, evenings. His work, our town, our lives were one, in rhythm. My sixth-grade schoolhouse window overlooked the road that connected my father's office to the town centre, and we would hear the whine of his engine as he accelerated recklessly along the road. His fast driving was famous in our town; he seemed to think he was immortal. My classmates would mutter as they heard his car speed by, 'There goes Dr Berwick.' They never even needed to look up.

My father was not just a very good doctor - he was that - but he was also, in a small town, royal. $\mathrm{He}$ was a person of privilege. His privilege was to enter the dark and tender places of people's lives our people. He knew secrets. He knew - we didn't - that Mary, browsing the market shelves next to us for her cereal, had miscarried again; that Nicholas, who sold us shoes, was struggling with alcohol; that Maureen, our Cub Scout leader, was quietly beside herself because Jonas was depressed and using drugs. He knew that Mrs Kraszinski, who taught fifth grade, had lung cancer and was going to die from it, even though she didn't know, because they hadn't told her yet.

For me, this was romance. I loved my father, but I also loved what he did; who he was in our town. I loved the way people looked at him, trusted him, named children 'Philip' after him. I loved that the constable would never give him a ticket, even though my father never saw a speed limit he didn't break. I loved that he knew secrets, and that he helped.

Thank you for the gift of Fellowship in this College. Given my roots - given my father - it is impossible for me to overstate how meaningful this is to me. If I can beg your pardon, I accept this Fellowship in honour of my father, Philip Berwick, from whom I received the compass for my own career. He died in 1995, at age 84 years.

Never, for a single day as a child, did I want to be anything but a doctor. Few days as an adult have been different. Why, when you can be royal, would you want to be anything else?

I once asked my father what he liked the most about being a doctor. He didn't say, 'Privilege,' he 
said, 'Mysteries ... solving puzzles.' He enjoyed the search for diagnosis, the making of sense from the clues and pieces. He knew this was important work, and he expected support for it. The hospital administrators, he assumed, served him. With his great responsibility came great authority. Sometimes arrogance came, too. I was 11 years old. At dinnertime, the telephone rang. A patient was calling. I watched my father listen, and then scowl. 'I'm the doctor,' he seethed. 'You're not. You'll get penicillin when I say, and not a moment sooner.' He slammed the phone handset down so violently that its plastic cradle shattered, sending shards into my beef stew.

The great medical sociologist, Eliot Freidson, in his masterpiece, Profession of Medicine, defined a profession as a work group that reserves to itself the right to judge the quality of its own work. ${ }^{1}$ Society, he said, cedes that right to the professional because of three assumptions: the assumption of expertise - that the professional has technical knowledge not accessible to the layperson; the assumption of altruism - that the professional will place the interests of those served above selfinterest; and the assumption of self-scrutiny - that professionals will regulate each other, without the need for outside interference. My father, every day, assumed the right to judge the quality of his own work - he was a harsh judge, harshest of all to himself. My mother died of cancer when I was 15 years old, and my father never forgave himself for not having detected it sooner, which was impossible. He shouldered fully and without complaint the obligations of technical mastery, altruism, and self-regulation. His bedside table was piled high with medical journals. He took only two vacations that I can recall.

My father was happy in his work, then. Today, I think, he might not be. Today, my father would be confused. His assumptions - the foundations of his personal mission and professional pride and joy - would be under attack. He would feel the same in the US or in the UK. He would have a rough time.

He would ask, 'Why do they doubt me so?' He would feel watched. He would not understand why. Strange words would swim around him, overheard from corridors he would not recognise, spoken by people he never met: 'accountability,' 'performance management,' 'pay for performance,' 'clinical guidelines,' 'patient empowerment,' 'the healthcare market,' 'value purchasing,' - words of surveillance, of suspicion. Not words of privilege; words of requirement, reward, and punishment. He would hear over and over again about systems and safety and standards. And, he would think it all to be nonsense, waste, off the point, insulting. He had trained, he would say, for a decade, up long nights and tense at the bedside, fighting off sleep to help, so that he could focus his time and skill and will and mind on the hard and noble task of solving mysteries for those who were suffering and putting their lives in his hands. I know what my father would say. He would say, 'Go away. Let me do my work. Leave me alone. You are wasting my time.' He would be angry. He would sound arrogant. He would once again shatter the telephone in disgust. He might say again, 'I am the doctor. You're not.'

I would want, of course, to ease my father's pain. What could I say to him?

I could say this: Dad, things change. You know that. When you were born, there were no airplanes or computers. Two world wars still lay ahead. You began to be a doctor before penicillin was discovered. Things change.

Technology has changed - it has taken over in some ways. And each technology brings with it specialisation. You took your own X-rays, right there, in your office. There were no CT scanners ... no MRls. That's over. You couldn't fit the machines into your office, even if you knew how to use them, which you do not ... which you cannot.

Audacity has increased, and with it, hazard. You watched, helpless, as people died from failing organs that today can be replaced. All children with leukemia died - remember Eleanor? Today, they live, unless they die from what we do to them.

With the technology to enable the audacity come new institutions to house it. Hospitals beep and throb with devices - monitors, pumps, respirators - that demand departments and spaces you never met or saw in your time. Each institution becomes its own master - self-referential, proud, inwardlooking; and the care that you once housed almost in totality in your office - the knowledge you stored almost in totality in your mind, these have been divided and re-divided into compartments named not just for diseases and organs, but for phases of disease and parts of organs. Could you have imagined, Dad, that one day there would be a hospital that cares only for cancer or a surgeon who works only on knees? Journals publish 10000 clinical trials every year. Memory fails; it's not up to the job anymore. What a harsh truth, Dad: you are not up to the job anymore - not alone.

And then, Dad, there is the money: trillions and trillions of dollars - in the US, one-seventh of our economy. Hospital CEO salaries rise into the millions of dollars. The founder of a healthcare insurance company leaves with $\$ 1$ billion in his pocket. The fate of entire governments rises or falls on whether or not they can keep some level of control over healthcare costs. Dad, you may still be 
royalty when you close the door and sit with a single, fearful patient. That patient, mostly, still trusts you - reveres you, but the reverence ends at the consulting room door, and, out there, outside your tiny kingdom, new dynasties rule. You have no idea what 'power' means today in health care. You have no idea. You once had power. But now, you share power.

And, Dad, remember that definition of a profession - 'reserving to itself the right to judge the quality of its own work'? That's over. I don't really know why. Somewhere along the way, the bond of public trust broke. Those assumptions technical mastery, altruism, and self-regulation lost the high ground. The assumption of technical mastery weakened as evidence grew of tremendous, unexplained variation in the patterns of practice, evidence that came with our new data systems. You never knew that Dr Harwich ordered $\mathrm{X}$-rays three times as often as you did. Dr Harwich didn't know either. Now, you both know, or can know, and so can the insurance company that pays you. And, frankly, so can the newspapers. Your private work space is now flooded with glaring light.

Altruism? What happens to faith in altruism when that insurance executive walks away with $\$ 1$ billion? When that drug company manipulates the evidence on the toxicity of its cash-cow drug? When hospital managers and doctors fight bitterly and openly about their own prerogatives? When politicians swap slogans instead of seeking wisdom?

Self-regulation? Shipman? Bristol? When the guilds oppose transparency? Your patients, remember, are also citizens. And they are a bit fed up with corporate scandal and the greed of wealth and the untruths of politicians and the half-truths of advertising. Your work has not stayed immune to fraying confidence in the public at large, not immune to the public's fear of harm from pollutants they cannot see and that no one admits to.

The millennial generation is ascending - the generation that makes its own self its project, that assumes choices, and that always doubts power the generation that says, 'I am the customer, and you're not,' and slams down the phone in anger. Your pride, which was your greatest asset in a trusting world, is now your greatest weakness in a doubting one. Consumerism is outpacing the social contract of professionalism.

Above all, Dad, this has changed: you now cannot do it all alone. The tasks of healing have simply passed the capacity of any single human mind, no matter how skilled or altruistic or selfsurveillant. You - and your patients - have now become irrevocably part of something far larger than yourself, and the craft of care has transformed into the machinery of care. Science and system have swamped art and autonomy. In return for possibility - in return for miracles - you have paid a dear price. The price is that you have lost control. If you define yourself by that sense of control, then the price has been even higher: you have lost self.

Is this the epitaph of profession, itself? Honestly, my father might think so. He would focus on the losses: the dear price of complexity, hazard, institutional growth, consumerism, transparency, financial costs, and, everywhere, doubt.

But, I would want to help my father; I would so badly want him to take a deep breath and intercept his own grief. I would try to help him say this to himself: 'I am a child of the Great Depression and I am a soldier of World War II. I have got through changes before and survived.' 'Maybe,' he might say, 'I'll take another look. There is a way through this. I know it.'

'How can I thrive - have pride - do with my life what I wish to do when the world has changed so much?', he would ask. 'When I can no longer thrive alone, but thrive only in interdependency? When I must ask less, "What do I do?" and more, "What am I part of?" When the light glares, and what I do is visible to others, even to strangers, even when I don't want it to be visible? When my patients wish to control knowledge and choices and devices and drugs that, before, I - only - controlled? How can I thrive when the weakness of my mind - of any mind - fails in the task of knowing what I need to know in order to help? When I cannot alone ensure the safety of the patients in my charge? Where is my pride when an email has to replace a touch on the arm?'

Is this the epitaph of profession, or the reconsideration of profession? In the former lies grief. In the latter, possibility.

What if we choose to change? Could we craft joy from loss, pride from revision, and excellence from invention?

Yes, we can, but not through reversion to the professionalism of the past - the professionalism of Freidson. Rescue - I think the stakes are no less than that - lies in the reinvention of professionalism in a world on new terms of engagement. The terms are these: complexity, interdependence, pervasive hazard, a changing distribution of power and control, and, borne on the back of technology, distributed, democratised capacities that my father could not ever have even imagined. Further, especially in my country, but even so in yours, the terms of engagement include a more precise and demanding sense of how health care links to the greater commons; a sense that we 
are stewards together, not just of healthcare resources, but of the limited resources, writ large, of our nations and our planet.

The new professional - the professional we need - is equipped, as my father, on the whole, was not equipped, with attitudes, skills, and knowledge like these:

- An embrace of citizenship in the greater whole that is health care, even when caring for a single patient. With respect to that whole, the system of care and caring, this means asking, not just, 'What do I do?' but also, 'What am I part of?'

- The skills to play that part, that membership role: cooperation, teamwork, inquiry, dialogue. These are more like the skills that make two parents great parents than those that make one artist a great artist.

- The skills less to know answers than to find answers. The romantic view - held tightly, romantically, still both by patients and physicians - that expertise means knowledge-in-the-mind is now simply a myth. It bears no reasonable relationship to the realities of the flow and accumulation of science in medicine today: thousands of journals, tens of thousands of studies, rapidly changing clinical armaments facing rapidly evolving disease challenges. My father said, 'I know.' The new professional says, 'I can find out.'

- Embrace of the authority and autonomy of patients and families in a wholly new distribution of power and knowledge. Some say that doctors and patients should now be partners in care. Not so, I think. In my view, we doctors are not our patients' partners; we are guests in our patients' lives. We are not hosts. We are not priests in a cathedral of technology. I have heard sarcastic doctors refer to the knowledgeable patient as 'internet positive,' as if that were a challenge or a mistake. It isn't. It is self-efficacy beyond anything my father could have imagined.

- Willingness to trade prerogative for reliability. That's a subtle trade; surely the toughest one for my father, to be handled with caution. Overshoot, and patients lose the benefit of the poetry and art of individual expression from each caring doctor; but, undershoot, and patients play dice - gambling that this particular doctor knows that particular fact - up to date, accurate, and precise. The aim is to promise every single patient the benefit of the best possible science, and that inevitably places the autonomy of the individual physician in some jeopardy. But, the new professional must make the choice: either treat the patient, your patient, according to your own store of knowledge and facts, or give up total self-reliance so as to promise the patient, your patient, treatment according to the entire world's store of knowledge and facts. That promise, the promise of science, is a different kind of promise from the one my father made. He promised to do his best; the new professional promises to do the world's best.

I could go on, but I need not. You in the RCGP know full well the transition of professional values, norms, expectations, and habits of which I speak. You are living through it here in the UK no less than we are in the US. And you know better than I do the troubles of that transition - the grief, the conflict, the suspicions, and the doubts.

But, maybe you also can see the daylight. As I would counsel my father, so I counsel you and myself: this is a time of loss, I know, but it is also a time of great discovery. I cannot promise you comfort; it was a glorious time when our privilege as physicians, earned through expertise, altruism, and self-regulation, sufficed for our communities and our tasks. We need now to find the joy and pride - we can find the joy and pride - that lie in slightly different places; the warmth of teamwork, the excitement of the expedition together into the vast terrain of modern knowledge, the humour and vivid ambition of the millennial generation, the benefits to our patients from the miracles of technologies, with their risks tamed by humility and infinite caution.

I may sound naïve; my father surely may have thought so. But I hold to this, and I would tell him: the essentials have not changed. What mattered to my father at the core - not in the casing, but at the core - has not changed. My reverence for his mission - not for his trappings, but for his mission - has not changed. We are more bound together now, depend more on each other, are more clearly part of possibilities larger than ourselves. But, still, we are fortunate. Still, it is our privilege to enter into the dark and tender places of people's lives, where, still, trust abounds when human beings turn to us in their pain. Still, there will come the middle of the night, and, with it, we still have our duty to meet and our quiet promise to keep: to bring comfort. And, in the morning, still, there will be thanks.

\section{Discuss this article}

Contribute and read comments about this article on the Discussion Forum: http://www.rcgp.org.uk/bjgp-discuss

\section{REFERENCE}

1. Freidson E. Profession of medicine: a study of the sociology of applied knowledge. Chicago, IL: University of Chicago Press, 1988. 